\title{
表面微細形状によるトラクション係数向上*
}

\author{
（第 1 報, 微細形状の方向性の影響）
}

\author{
南 部 俊 和*1, 保 田 芳 輝 ${ }^{* 1}$ \\ 牛嶋 研 史 ${ }^{* 1}$, Dong $\mathrm{ZHU}^{* 2}$
}

\section{Increase of Traction Coefficient due to Microtexture \\ (1st Repor, Effect of Orientation in Microtexture)}

\author{
Toshikazu NANBU*3, Yoshiteru YASUDA, \\ Kenshi USHIJIMA and Dong ZHU \\ ${ }^{* 3}$ Nissan Research Center, Nissan Motor Co. LTD., \\ 1 Natsushima-cho, Yokosuka-shi, Kanagawa, 237-8523 Japan
}

\begin{abstract}
Improving the traction coefficient of a traction drive system is a key factor in obtaining a smaller, lighter unit and also greater torque capacity. This study focused on the microtexture of the rolling elements, and effect of orientation in microtexture was examined with the aim of improving the traction coefficient in the viscous region. Three textures-dimple, transverse and longitudinalwere examined using a 4-roller tester that enabled tests to be conducted under high pressure and high rolling speed. As a result, it was found that the longitudinal surface texture is the best for improving the traction coefficient. The results obtained with EHL analysis showed that only the surface texture with longitudinal grooves improved the traction coefficient, just as in the tests conducted with the 4roller tester.
\end{abstract}

Key Words : Tribology, Surface Roghness, Nano \& Micro Machining, Lubrication, Friction

\section{1. 粕言}

トラクションドライブは, 転がりすべり接触するディスク 間に形成される弾性流体潤滑(EHL:Elastohydrodynamic Lubrication）状態の油膜のせん断力により動力を伝達す る機構であり, 高い圧力粘度係数を有する特殊な油が使 用される. Evans \& Johnson ら ${ }^{1)}$ によるトラクション油の 状態図上で, 実際に自動車に車載されるトロイダル CVT の使用条件を考えると, 低速・高面圧条件の弾塑性状態 のみならず, 高速·低面圧条件の粘弹性状態も存在する. この高速·低面圧条件の粘性状態の油により,トラクション 係数は低下するが, 粘性状態の油を塑性状態に近づけ ることができれば, トラクション係数を向上でき, 押し付け 荷重を小さくできるため, システムの小型, 軽量化および 高効率化に寄与できる.トラクション係数を向上させる技 術としては,トラクション油の性能向上や転動体表面微細 形状の改良による向上が考えられる. 前者の場合, 分子

* 原稿受付 2007 年 1 月 12 日.

*1 正員, 日産自動車(株)（䑬237-8523 横須賀市夏島町 1).

*2 Eaton Corporation (26201 Northwestern Highway Southfield, MI 48037).

E-mail : t-nanbu@mail.nissan.co.jp
動力学を用いた新規基油に関する研究 ${ }^{2)}$ が始まって いるが, さらに高いトラクション係数を発現する新規の化 合物を発見する必要があること, 低温特性との両立を図 る必要があること, さらには, 高卜ラクション係数を有する 油は,トラクション部以外の接触部における摩擦損失を増 大させることなどの理由から, 開発には多くの解決すべき 課題を有する. 一方, 後者に関しては, 必要な箇所の卜 ラクション係数向上が可能となるが, 一般には粗さ突起部 での金属接触による耐久性の悪化を㲘念し, 出来るだけ 粗さを小さく抑えようとするのが現状であり，積極的に表 面微細形状をトラクション係数向上に利用しようという研 究はほとんど見られない.

著者らは, これまでに, 転動部の表面粗さがせん断応 力に及ぼす影響を 2 円筒試験機を用いた, 比較的, 低面 圧, 低周速条件において検討し, 表面粗さを制御するこ とで金属接触を小さく留めながら, せん断応力を向上で きる可能性を示した ${ }^{3 \vdash-4)}$.

また,これらの結果から, 実機相当条件のトラクション 油の物性值を使用し, スピン等が存在する2次元摺動 下のトラクション特性を, 粘弹性と塑性の直列レオロジ 一モデルを採用し，表面粗さが実機トラクション性能一 
与える影響を検討し，実際のトロイダル CVTにおいても 表面粗さの影響はきわめて大きく, 表面粗さを制御すれ ば,トラクション係数が向上できる可能性を見出した ${ }^{5)}$.

本研究では, 実機相当の高面圧, 高周速の試験が可 能な4円筒試験機を用い, 表面微細形状の方向性が卜ラ クション係数に及ぼす影響について実験的に検討した. また, 表面微細形状を最適化していくために，実験によ る試行錯誤のみのアプローチでは多大な工数を要する ことから，EHL解析によるシミュレーションの活用を検討し た. 特に熱の影響を考慮した EHL 解析は, 定量的に評 価することは現状では困難と考えられるが，計算結果と 実験結果との比較を行うことで, 定性的な解析ツールとし ての可能性を検討した結果を報告する.

\section{2. 実験装置および実験方法}

2.14 円筒試験機 実験には, 図 1 に示寸, 高面 圧, 高周速での試験が可能な 4 円筒試験機を用いた. 試 験に用いた円筒はいずれも, 外径 $60 \mathrm{~mm}, \mathrm{HRC60}$ の SUJ2 製である. フラット円筒を中心に配置し，その周りに 軸方向曲率半径 $\mathrm{R} 30 \mathrm{~mm}$ の円筒を 120 位置に 3 個配置 した. 中心に位置するフラット円筒とその周りに配置した 3 つの円筒の間にすべりを与え, その時に発生するせん 断力をフラット円筒を支える中心軸に設置したトルク計を 用いて計測し，押し付け荷重で除することによりトラクショ ン係数を算出した. また, ピーリング損傷の代用特性とし て, 金属接触の程度を定性的に評価することを目的に, 接触電気抵抗法を用いた油膜形成率の測定を行った. 油膜形成率は, 運転中の分離電圧を完全分離状態にお ける電圧で除した百分率であらわした值と定義し以下の 解析において使用した. 試験は表 1 に示すトラクション油 $\mathrm{KTF} 1$ を用い，表 2 に示すように, 平均転がり速度 $30 \mathrm{~m} / \mathrm{s}$ ， すべり率 $0 \sim 3 \%$ ，平均接触圧力 $0.7,1.5,2 \mathrm{GPa}$ の 3 水準の条件下で行った. トラクション油は, $150^{\circ} \mathrm{Cl}$ 加熱 し, 各円筒の入り口部に $0.8 \mathrm{~L} / \mathrm{min}$ で強制給油した.

Table 1 Characteristics of Traction oil

\begin{tabular}{|c|c|c|}
\hline & $40^{\circ} \mathrm{C}$ & $100^{\circ} \mathrm{C}$ \\
\hline Viscosity, $\mathrm{mPa} \cdot \mathrm{s}$ & 34.07 & 5.407 \\
\hline Density, $\mathrm{g} / \mathrm{cm}^{3}$ & 0.945 & 0.908 \\
\hline $\begin{array}{c}\text { Pressure-Viscosity } \\
\text { exponent; } \alpha, \mathrm{GPa}^{-1}\end{array}$ & 25.9 & 16.06 \\
\hline
\end{tabular}

Table 2 Test conditions

\begin{tabular}{|l|c|c|c|}
\hline Rolling speed, $\mathrm{m} / \mathrm{s}$ & \multicolumn{3}{|c|}{30} \\
\hline Slip ratio, \% & \multicolumn{3}{|c|}{$0 \sim 3$} \\
\hline Mean contact pressure, GPa & 0.7 & 1.5 & 2 \\
\hline Semimajour axis of Hertzian contact ellipse (b), $\mathrm{mm}$ & 0.38 & 0.82 & 1.08 \\
\hline Semiminor axis of Hertzian contact ellipse (a), $\mathrm{mm}$ & 0.23 & 0.51 & 0.67 \\
\hline Oil temperature, ${ }^{\circ} \mathrm{C}$ & \multicolumn{4}{|c|}{150} \\
\hline
\end{tabular}

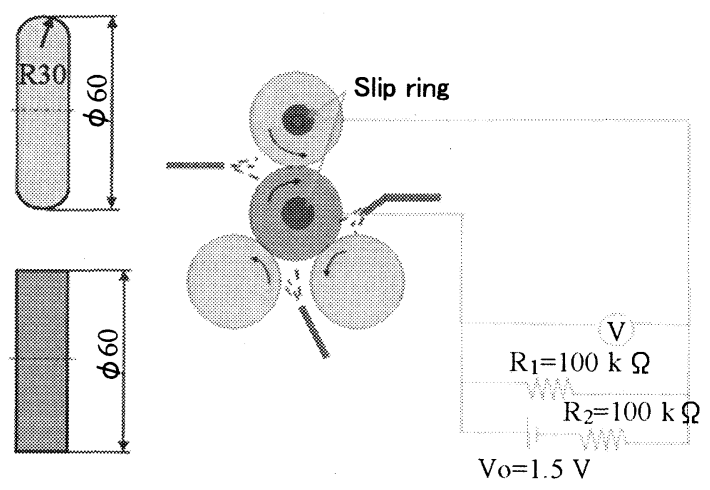

Fig. 1 Schematic diagram of 4-roller tester

2.2 表面微細形状 トラクション係数および油膜形 成率に及ぼす微細形状の方向性の影響を検討する目的 で, 表 3 に示す仕様のディンプル, 直交溝および円周溝 の 3 種類の微細形状をフラット円筒外径面に形成した. 軸方向曲率半径 R30mm 円筒表面は, Ra0.02 $\mu \mathrm{m}$ の超仕 上げ加工とした. ディンプルおよび直交溝に関しては, マスクブラスト処理により形成した. すなわち, 光リソグラ フィにより形成した, 微細パターンを有する樹脂製マスク を円筒表面に貼り付け, その後, 平均粒径 $20 \mu \mathrm{m}$ の $\mathrm{Al}_{2} \mathrm{O}_{3}$ セラミック粒子を投射圧 $0.2 \mathrm{MPa}$ で所望の深さになるまで 投射し，その後，凹部微細形状周辺にできたエッジ部の 盛り上がりを粓径 $9 \mu \mathrm{m}$ のテープラップフィルムにより除去 し, 平坦部表面を Ra0.01 $\mu \mathrm{m}$ に仕上げた. また, 円周溝は, 工具刃先曲率半径 $50 \mu \mathrm{m}$ の $\mathrm{c}-\mathrm{BN}$ 切削工具を用いた切削 により $120 \mu \mathrm{m}$ ピッチの微細螺旋溝を形成後, 平均粒径 $9 \mu \mathrm{m}$ のテープラップフィルムにより凸部表面を Ra0.01 $\mu \mathrm{m}$ に仕上げると同時に, 凹部の深さを $1 \mu \mathrm{m}$ となるように調整 した. 図 2 は, 白色干涉式形状測定器(WYKO)により計 測した各表面微細形状を示す。 
Table 3 Surface textures used in experiment

\section{Longitudinal \#2}

Groove depth : $1.2 \mu \mathrm{m}$, Groove pitch: $130 \mu \mathrm{m}$, Groove width: $22 \mu \mathrm{m}$

\section{Dimple \#2}

Dimple depth: $1.0 \mu \mathrm{m}$, Dimple diameter. $65 \mu \mathrm{m}$, Pit area ratio:30\%

\section{Transverse \#1}

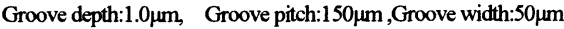

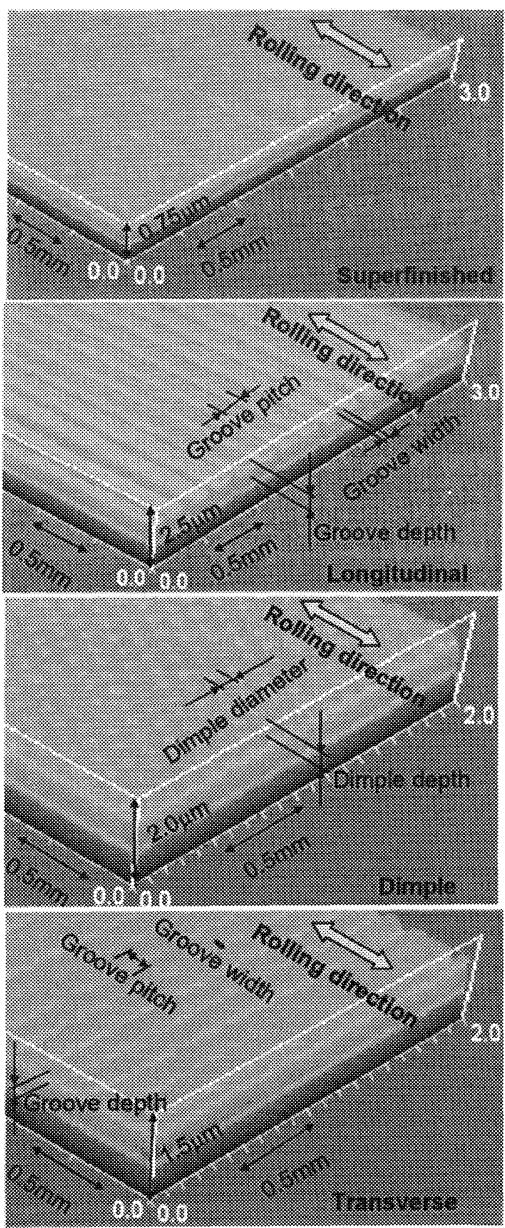

Fig. 2 Examples of microtexture

\section{EHL計算手法}

EHL 解析では, Reynolds 式, 弾性変形式および油の 高圧粘度式を連立して解くことになるが, 特にトロイダル CVTのような過酷な条件 (高圧力粘度係数, 高面圧, 低 油膜厚さ)において収束解を得ることは一般に困難であ る. 著者らの一人は, 油膜厚さが極めて零に近い場合に
は, Reynolds 方程式の左辺の圧力流れ項を零とし, 収束

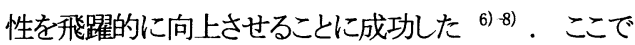
は, 本解析手法を用いて, 白色光干涉式形状測定機 WYKOにより計測した 3 次元形状データを計算に取り込 み, 決定論的な表面粗さの取り扱いにより, 表面微細形 状が油膜厚さおよびトラクション係数に及ぼす影響を評 価た

本EHL 解析手法は，接触部を流体潤滑領域之突起 接触領域の 2 領域に分類する. 流体潤滑領域は Reynolds 式により支配され，時間項を含む Reynolds 式 は(1)式で表される。

$$
\frac{\partial}{\partial x}\left(\frac{\rho}{12 \eta *} h^{3} \frac{\partial p}{\partial x}\right)+\frac{\partial}{\partial y}\left(\frac{\rho}{12 \eta *} h^{3} \frac{\partial p}{\partial y}\right)=U \frac{\partial(\rho h)}{\partial x}+\frac{\partial(\rho h)}{\partial t}
$$

ここで, $\mathrm{h}$ : 油膜厚さ, $\mathrm{p}$ : 流体圧力, $\rho$ : 潤滑油密度, $\eta^{*}$ : 有効粘度 $\mathrm{U}$ : 平均転がり速度, $\mathrm{t}$ : 時間, $\mathrm{x}$ : 転がり方向の位置, $\mathrm{y}$ : 転がり方向と直交方向の位置 をそれぞれ示す。

Reynolds 式は本質的には流量バランスを記述する式 であるため, 油膜厚さが零となり接触が発生すれば, 圧 力流れを記述する Reynolds 式の左辺は零となり, 右辺の みにより記述されることになる. すなわち，

$$
U \frac{\partial(\rho h)}{\partial x}+\frac{\partial(\rho h)}{\partial t}=0 \text { at } h=0
$$

さらに, スクイーズ項が零である場合には, (2)式は (3)式で示される.

$$
\frac{\partial h}{\partial x}=0 \text { where } \frac{\partial h}{\partial t}=0
$$

$H=\frac{h}{b} \geq 0.000001$ の場合には, (1)式を,

$H=\frac{h}{b}<0.000001$ の場合には(2)あるいは(3)式

を用いた.ここで, $\mathrm{H}$ は無次元油膜厚さを表し, 油膜厚さ

$\mathrm{h}$ と接触楕円長径 の半分 $\mathrm{b}$ の比で表わされる.

幾何学形状により求まる油膜厚さ式は(4)式で示され る.

$h=h o(t)+B_{x} x^{2}+B_{y} y^{2}+V(x, y, t)+\delta_{1}(x, y, t)+\delta_{2}(x, y, t)$ 
$B_{x}, B_{y}$ は接触物体の幾何形状に関する定数, $\delta_{1}$ および $\delta_{2}$ は物体 1 おび2における $\mathrm{x}, \mathrm{y}$ 方向と垂直方向の位置, $V$ は(5)式により表される弾性変形式である.

$$
V(x, y, t)=\frac{2}{\pi E^{\prime}} \iint_{\Omega} \frac{p(\xi, \varsigma)+p_{c}(\xi, \varsigma)}{\sqrt{(x-\xi)^{2}+(y-\varsigma)^{2}}} d \xi d \varsigma
$$

ここで, $p$ は流体圧力, $p_{c}$ は突起接触圧力を示す. (1) 式における有效粘度 $\eta^{*}$ は(6)式に示す非二ュートン流 体である, Eyring 粘性 ${ }^{9)}$ を仮定する .

$$
\frac{1}{\eta *}=\frac{1}{\eta} \frac{\tau_{o}}{\tau_{1}} \sinh \left(\frac{\tau_{1}}{\tau_{o}}\right)
$$

ここで, $\tau_{0}$ ：特性せん断応力， $\tau_{1}$ ：せん断応力を示す. 粘度 $\eta$ は(7)式に示す Banusの式を用いる.

$$
\eta=\eta_{o} \exp (\alpha p)
$$

また圧力と密度の関係式は，(8)式を用いる. ここで, $\rho_{0}$ は大気圧下の密度を示す.

$$
\rho=\rho_{o}\left(1+\frac{0.6 \times 10^{-9} p}{1+1.7 \times 10^{-9} p}\right)
$$

トラクション力は圧力および油膜厚さの計算結果に基づ き計算される.トラクションの計算は, (9)式に示す Bair-Winerによる粘弾性モデル ${ }^{10)}$ を用いた.

$$
\dot{\gamma}=\frac{\dot{\tau}}{G}-\frac{\tau_{L}}{\eta} \ln \left(1-\frac{\tau}{\tau_{L}}\right)
$$

限界せん断弾性係数 $G$ および限界せん断応力 $\tau_{L}$ は, そ れぞれ(10)式に示す Dysonの式 ${ }^{11)}$ より推定した.

$G(p, T)=1.2 p /(2.52+0.024 T)-10^{8}$

$\tau_{L}(p, T)=0.25 G$

\section{ここで、Tは潤滑油温度を示す。}

一方, 接触部におけるせん断応力は, 突起接触による摩 擦係数 $\mu$ を一定值とすれば(11)式により求まる.

$$
\tau=\mu p_{c}
$$

(9)式による流体潤滑膜のせん断応力と(11)式による突 起接触によるせん断応力を接触部内において積分すれ ば全摩擦力が算出できる.

\section{4. 実験結果および考察}

4. 1 表面微細形状の方向性の影響 図 3, 図 4 は, 油温 $150^{\circ} \mathrm{C}$, 周速 $30 \mathrm{~m} / \mathrm{s}$, 平均面圧 $2 \mathrm{GPa}$ の条件におけ る, ディンプル, 直交溝, 円周溝, 超仕上げ面のトラクショ ン曲線および接触電気抵抗法により測定した油膜形成率 を示す。

いずれの表面微細形状においても, 最大トラクション 係数を示す滑り率以上では, 滑率の増加に伴い, トラク ション係数および油膜形成率とも減少する傾向を示した. これは, せん断発熱による油膜内の温度上昇に伴い, ト ラクション油の粘度が低下したためと考えられる。

ハーフトロイダル CVT のような実際のトラクションドライ ブではスピンによる発熱を考慮する必要がある.そこで, 今回は, 図3および図4に示した曲線の内, 滑り率 $3 \%$ の 時点での, トラクション係数および油膜形成率を用いて, データ解析を行った.

図 5 および図 6 は, 平均面圧とトラクション係数および 油膜形成率の関保を示す.

いずれの表面微細形状においても,トラクション係数は, 平均面圧 $1.5 \mathrm{GPa}$ の時に最も大きく, $0.7 \mathrm{GPa}$ および, 2GPa の時にはむしろ低下した. 超仕上げ面との比較に おいて, ディンプルおよび直交溝のトラクション係数は, $1.5 \mathrm{GPa}$ の時は多少の増加はみられるものの, それ以外 の面圧では, トラクション係数は減少する結果となった. ディンプルおよび直交溝の油膜形成率は, 超仕上げに 比べて, 低下しており，金属接触が増加した. すなわち， ディンプルおよび直交溝のトラクション係数は金属接触 が増加したにもかかわらず, トラクション係数が減少する 結果となった. 一方, 円周溝は, 油膜形成率を超仕上げ とほぼ同等に保ったまま,トラクション係数を向上できるこ とがわかった. 特に, 低面圧側でのトラクション係数を著 しく増加できることがわかった。

図 7 は, Evans らの計算式 ${ }^{12)}$ により推定した油膜内 温度を用いて, 実験で求めたトラクション係数を整理した 結果を示す. また, 図中実線は, Johnson らの手法を用い, 
4 円筒試験機において, 実測した, 限界せん断応力から 算出した限界卜ラクション係数 ${ }^{13)}$ を示す. 最む大きなトラ クション係数を示した円周溝でさえ, 限界トラクション係数 に比べると低い值を示している. 溝の間隔や深さなどの 形状パラメータを最適化することで, さらにトラクション係 数を向上できる可能性があることを示唆していると考えら れる. 試験後の 3 次元 SEMによる表面の観察では, リン 酸皮膜の生成が認められた.このことは, 金属接触が発 生していたことを示すが, 超仕上げにも同様の皮膜が形 成されており, 今後, 更にトラクション係数を向上するた めには, ピーリングなどの表面損傷などの耐久性との両 立を図りながら, 形状最適化を行う必要があると考えられ る.

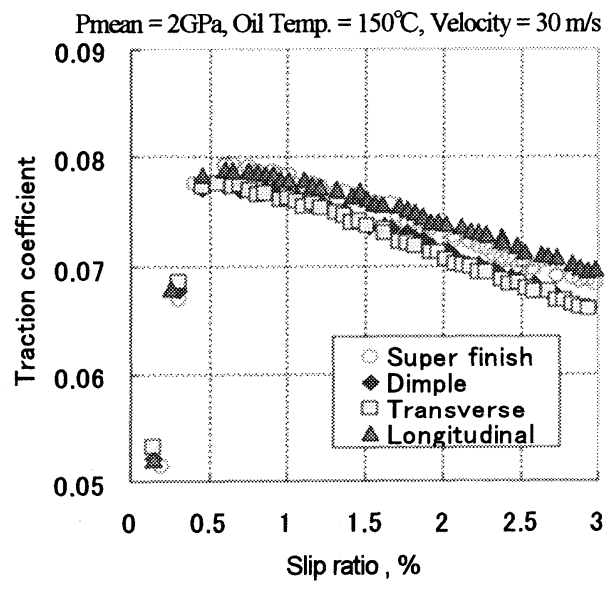

Fig. 3 Relationship between slip ratio and traction coefficient

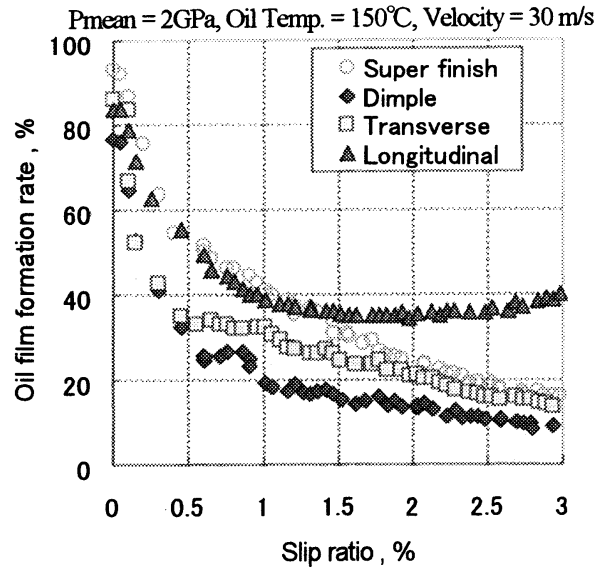

Fig. 4 Relationship between slip ratio and oil film formation rate
Oil Temp. $=150^{\circ} \mathrm{C}$, Velocity $=30 \mathrm{~m} / \mathrm{s} \quad$, Slip ratio $=3 \%$ 0.080

0.075

0.070

0.065

0.060

0.055

0.050

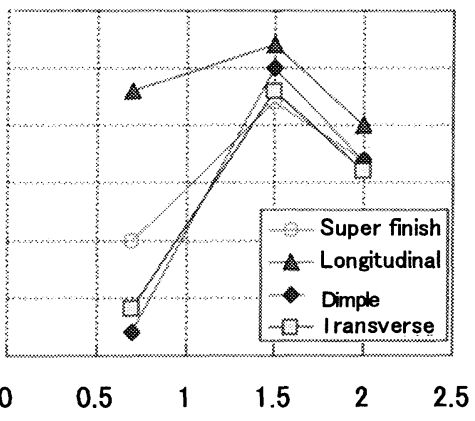

Mean contact pressure, $\mathrm{GPa}$

Fig. 5 Relationship between mean contact pressure and traction coefficient

Oil Temp. $=150^{\circ} \mathrm{C}$, Velocity $=30 \mathrm{~m} / \mathrm{s}$, Slip ratio $=3 \%$

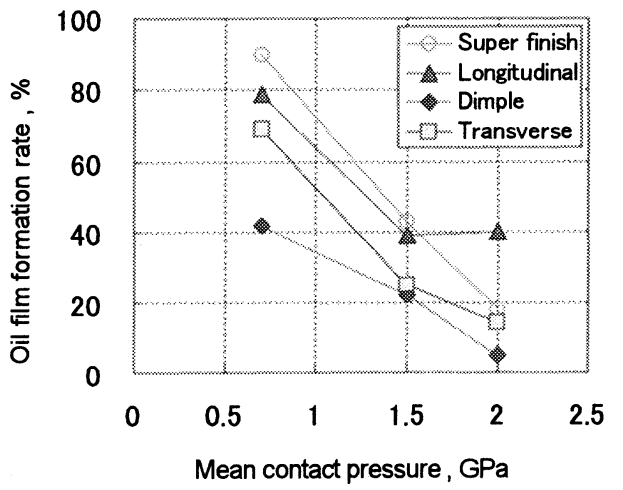

Fig. 6 Relationship between oil film formation rate and mean contact pressure.

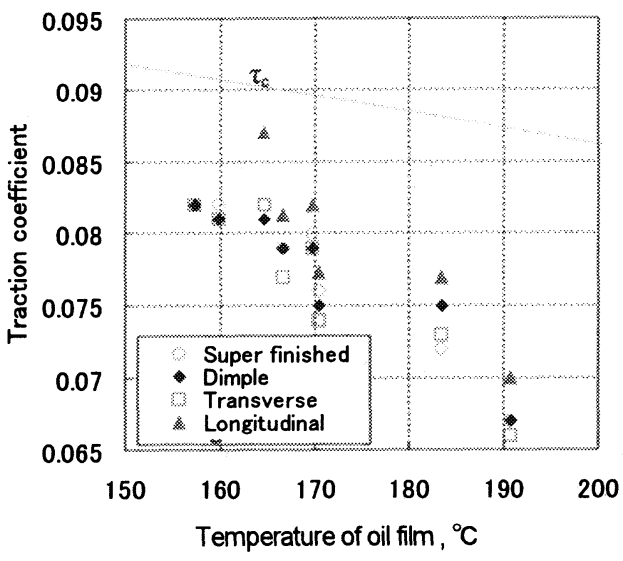

Fig. 7 Relationship between temperature of oil film and traction coefficient. 


\section{2 Smooth 表面における従来解析結果との比較}

表 4 に示す低速·高面圧条件を仮定した Casel と 高速·低面圧条件を仮定した Case2 の 2 条件において 計算を行った. まず, Case1条件での, smooth 表面に対 するEHL解析を実施した結果を図8に示す. また, 図9 は図 8 のセンターラインにおける無次元油膜厚さ $\mathrm{H}$ お よび接触応力比 $\mathrm{P} / \mathrm{Ph}$ を示す. 無次元油膜厚さ $\mathrm{H}$ は油 膜厚さ $\mathrm{h}$ と接触棈円短径の半分 $\mathbf{b}$ との比であり, 接触応 力比 $\mathrm{P} / \mathrm{Ph}$ は smooth 表面における発生応力 $\mathrm{P}$ と平滑 面におけるへルツ応力 $\mathrm{Ph}$ との比を示す。

Hamrock-Dowson $の$ 式 ${ }^{14)}$ 上り算出される中央油膜厚 さが $0.2 \mu \mathrm{m}$ 程度であるにもかかわらず, 本解析結果で は, 接触部中央において無次元油膜厚さ $\mathrm{H}=\mathbf{h} / \mathbf{b}$ 0.000001 以下々極めて小さい值を示すことがわかった. この乘離は, Hamrock-Dowson の式が, 比較的, 軽荷 重条件下での数值計算結果からの数值実験回帰式で あり，本解析条件のような高面圧下に適用する場合に は, 過大評価する可能性も考えられる. 例えば, 本計算 手法を用いて算出した計算結果は, 無次元速度の低下 と共にHamrock-Dowsonの式より算出した結果に対して 乘離が発生する ${ }^{15)}$. 本結果の妥当性については, 更 なる検証が必要であるが, 超仕上げ加工が施された実 際のトロイダル CVT のトラクション面において、耐久試 験後の表面粗さが Ra0.01 $\mu \mathrm{m}$ 程度に鏡面化されている 事実功も，少なからず金属接触は発生していると考え られる。そこで、以降では、本計算手法を用いて, 表面 微細形状がトラクション係数に及ぼす影響を計算し, 先 に述べた実験結果と比較検討し, 本計算手法の微細形 状設計ツールとしての可能性を検討した.

Table 4 Calculation conditions for EHL analysis

\begin{tabular}{|l|l|l|}
\hline \multicolumn{1}{|c|}{ Parameter } & Casel & Case2 \\
\hline Effective Radius Rx $(\mathrm{mm})$ & 20.33 & 28.81 \\
\hline Effective Radius Ry $(\mathrm{mm})$ & 120.0 & 120.0 \\
\hline Visicosity $\eta_{0}(\mathrm{~Pa} \cdot \mathrm{s})$ & 0.00240 & 0.00164 \\
\hline Density $\rho_{0}\left(\mathrm{~g} / \mathrm{cm}^{3}\right)$ & 0.7905 & 0.7712 \\
\hline Pressure-Viscosity Exponent $\alpha(1 / \mathrm{GPa})$ & 12.16 & 9.11 \\
\hline Load W $(\mathrm{N})$ & 43240 & 28701 \\
\hline Mean Contact Pressure Pmean (GPa) & 2.59 & 1.96 \\
\hline Semimajour axis of Hertzian contact ellipse b $(\mathrm{mm})$ & 4.12 & 3.45 \\
\hline Semiminour axis of Hertzian contact ellipse a $(\mathrm{mm})$ & 1.29 & 1.35 \\
\hline Rolling Speed U $(\mathrm{m} / \mathrm{s})$ & 14.1 & 30.0 \\
\hline
\end{tabular}

Effective Elastic Modulus E'=232GPa

Slide-to Roll Ratio S=3\%

Rolling direction: $\mathrm{X}$-axis

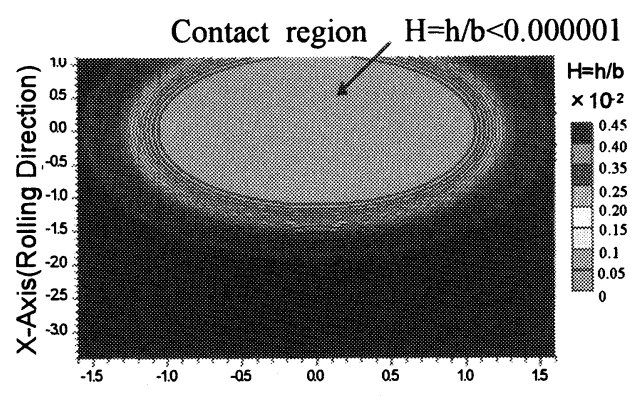

F Y-Axis(Orthogonal axis to the rolling direction) case of smooth surface under Case 1.

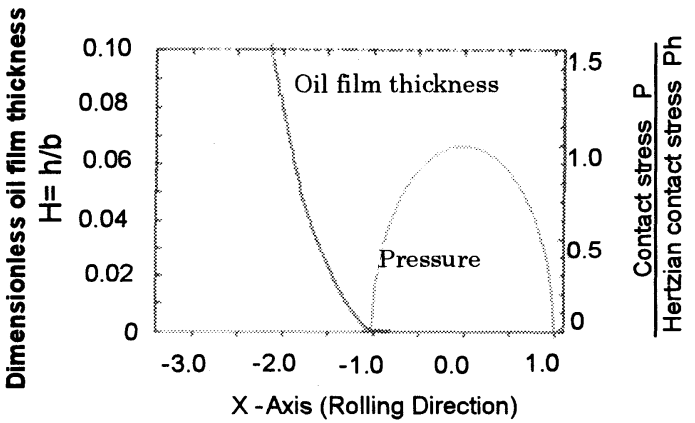

Fig. 9 Oil film thickness and pressure along the center line

4. 3 EHL 解析による検討結果 ディンプル, 直交溝, 円周溝の 3 種類の表面微細形状を用いて、EHL 解析を 行い, 粗さの方向性がトラクション特性に及ぼす影響を実 験結果と比較検討した. 表 3 の仕様に加えて、表 5 の仕 様について実際に表面微細形状を試作し，WYKOによ り表面形状データを取得後, 計算に使用した.

計算は, 前章と同様, 低速·高面圧条件を仮定した Casel と高速・低面圧条件を仮定した Case2の 2 条件で 実施した.

Table 5 Surface texture used in calculation

(Unit; $\mu \mathrm{m}$ )

\begin{tabular}{|c|c|}
\hline 1. Superfinished surface & $0.02 \mu \mathrm{m} \mathrm{Ra}$ \\
\hline 2 Longitudinal\#2 & Groove depth: 1.2 ; groove pitch: 130; groove width: 22 \\
\hline 3. Longitudinal\#3 & Groove depth: 2.5 ; groove pitch: 200 ; groove width: 31 \\
\hline 4. Longitudinal \#4 & Groove depth: 3.7 ; groove pitch: 300 ; groove width: 38 \\
\hline 5 Dimple\#1 & Dimple depth: 2.0 ; dimple dia 65 ; area ratio: $30 \%$ \\
\hline 6 Dimple\#2 & Dimple depth: 1.0 ; dimple dia 65 ; area ratio: $30 \%$ \\
\hline 7 Transverse \#1 & Groove depth: 1.0 , groove pitch 150 ; groove width: 50 \\
\hline 8. Transverse\#2 & Groove depth: 2.0 ; groove pitch.: 150; groove width: 50 \\
\hline
\end{tabular}



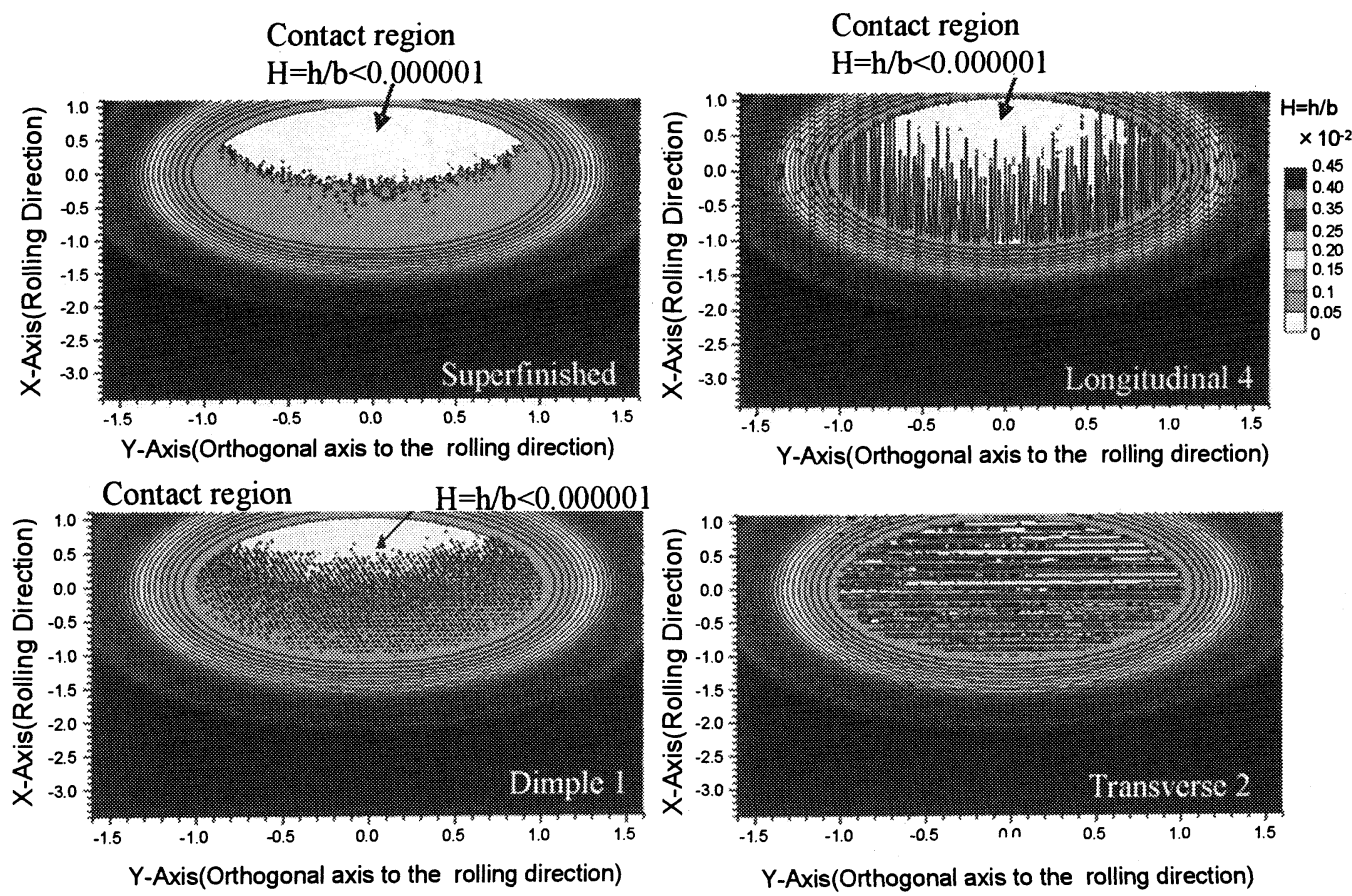

Fig. 10 Examples of calculated non-dimensional oil film thickness distribution in case 2

図 10 は一例として、Case2 条件で計算した各表面微 細形状における無次元油膜厚さ $(\mathrm{H}=\mathrm{h} / \mathrm{b})$ の分布を示す. 比較のため, 超仕上げの結果も併せて示す.

油膜中央部は, $\mathrm{H}=\mathrm{h} / \mathrm{b}<0.000001$ と極めて油膜厚さが薄 いことを示すが, ディプルや直交溝の場合はこの油膜 厚さが極めて薄い部分が減少している.このことは, デ インプルや直交溝の負荷容量が増加し, 流体膜による荷 重分担率が増加したことを示すと考えられる.

図 11 はトラクション係数の計算結果を示す. ディンプ ルおよび直交溝のトラクション係数は, Casel 条件およ び, Case2 条件いずれにおいても, 超仕上げ加工よりも $10 \%$ 30\%程度低下する結果が得られた.

これは, 前述のように, ディンプルや直交溝の部分の 負荷容量の増加にともない流体膜による荷重分担率が 増加したことが理由と考えられる.

これに対して, 円周溝は低速·高面圧条件を仮定した Casel では, 超仕上げ面のトラクション係数とほぼ同 等であったが, 高速・低面圧条件を仮定した Case2 条件 では, トラクション係数が $10 \%$ 程度向上する結果が

得られた.この理由としては, 円周溝の場合には油の 排出性が良いために, 直接接触による荷重分担率が増 加し, その結果, トラクション係数が増加していると考えら れる.

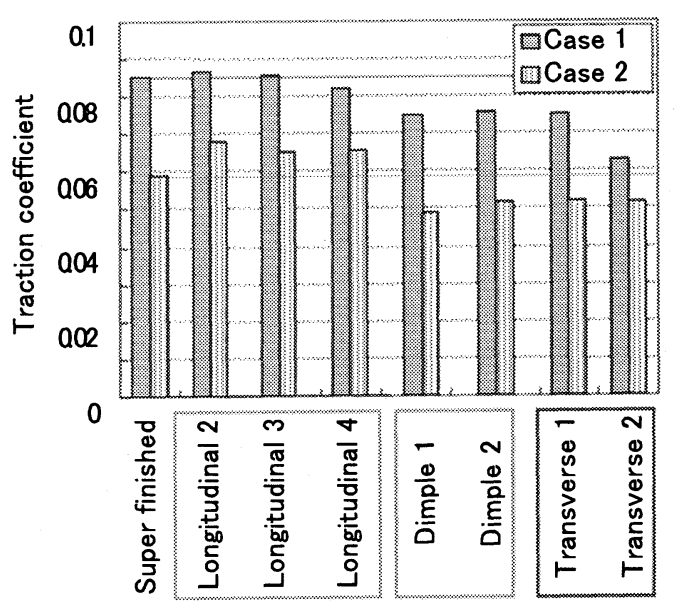

Fig. 11 Calculation results of traction coefficient in several surface textures

これらの結果は, Patir-Cheng の平均流モデル ${ }^{16)}$ の結 果と定性的に一致しており,トラクション特性は, 混合潤 滑下における油膜と直接接触による荷重の分担割合で 説明できると考えられる. 
また, 高速·低面圧条件を仮定した Case2 のみトラクシ ヨン係数が向上する理由としては, Casel では接触楕円 中の油がほぼ弹塑性状態にあるのに対して, Case2 の場 合, 油がより粘性的な特性を示すため, 表面微細形状に より弾塑性的な特性に近づけることでトラクションが向上 していると考えられる.

\section{5. 結言}

トラクション係数向上を目的に, トラクション部の表面微 細形状に着目し, 微細形状の方向性について, 実機相 当の条件での詿験が可能な 4 円筒試験機を用いて実験 を行った. また, 表面微細形状を考慮した EHL 解析を行 い, 定性的な微細形状設計ツールとしての可能性を検討 した. 得られた結果をまとめると以下の通りである.

(1)円周溝, ディンプル, 直交溝の 3 種類の形状につい て高面圧，高周速の試験が可能な 4 円筒試験機を用い た実験を行い,トラクション係数を向上しつつ, 金属接 触を小さく抑制できる表面微細形状として, 転がり方向 に平行な円周溝が優れることを見出した。

(2)弾性流体潤滑解析を適用し, 円周溝, デインプル, 直 交溝の 3 種類の形状について計算を行い, 上記実験結 果と同様に円周溝のみトラクション係数を向上できる結 果を得た.このことより, 定性的な表面微細形状設計ツ 一ルとして本解析が有効であることがわかった。 なお，第 2 報にて,トラクション倸数を向上しつつ, 金 属接触を小さく抑制できる, 転がり方向に平行な円周溝 に関して, その形状パラメータの感度解析を行い, CVT バリエータへ適用した結果を報告する.

\section{参考文献}

1) Evans , C. R and Johnson, K. L., " Regimes of traction in elastohydrodynamic lubrication " , Proc. Instn Mech. Engrs., 200, C5, (1986) 313.

2) KAMEI, D., ZHOU, H., SUZUKI, K., KONNO, K., TAKAMI, S., KUBO, M. and MIYAMOTO, A., " Computational Chemistry Study on the Dynamics of Lubricant Molecule under Shear Conditions ", Tribology Int., 36 (2003) 297.

3) Nanbu, T., Chiba, N., Kano, $M$ and Ushijima, $K$, " The effect of surface texture on traction performance in a traction drive", JSAE Review, 24(2003) 135.

4) Nanbu, T., Chiba, N., Kano, $M$ and Ushijima, $K$, "The effect of surface roughness on elastohydrodynamic traction (1) ", Lubrication Science 17-4, August (2005) 281.

5) Ushijima, K, Nanbu, T., Chiba, N., Kano, M and Aoyama, S., "The effect of surface roughness on elastohydrodynamic traction (2) " , Lubrication Science

\section{4, August (2005) 403}

6) Hu、Y.Z. and Zhu, D., " A Full Numerical Solution to the Mixed Lubrication in Point Contacts ", ASME Journal of Tribology, 122, (2000) 1.

7) Zhu , D. and Hu, Y. Z., "A Computer Program for the Prediction of EHL and Mixed Lubrication Characteristics, Friction, Subsurface Stresses and Flash Temperatures Based on Measured 3-D Surface Roughness ", Tribology Transactions, 44, (2001) 383.

8) Zhu, D. and Hu, Y.Z., " Effects of Rough Surface Topography and Orientation on the characteristics of EHD and Mixed Lubrication in Both Circular and Elliptical Contacts ", Tribology Transactions, 44, (2001) 391.

9) Yang, P., and Wen, S., " A Generalized Reynolds Equation for Non-Newtonian Thermal Elastohydrodynamic Lubrication " , ASME Joumal of Tribology, 112 (1990) 631.

10) Bair, S., and Winer, W. O., "A Rheological Model for Elastohydrodynamic Contacts Based on Primary Laboratory data ", ASME Joumal of Tribology, 101 (1979) 258.

11) Zhu, D., and Cheng. H. S., " An Analysis and Computational Procedure for EHL Film Thickness, Friction and Flash Temperature in Line and Point Contacts ", Tribology Transactions, 32 (1989) 364.

12) Evans, C. R and Johnson, K. L., " The rheological properties of elastohydrodynamic lubricants ", Proc. Instn. Mech. Engrs., 200, C5 (1986) 303.

13) Watanabe, J., Ushijima, K. and Oshidari, T., " A Study of Traction Characteristics of an Automotive Toroidal CVT: Experimental Analysis due to roller tester " ( $1^{\text {st }}$ Report), Proceedings of 2000 Annual Conference of the Japan Society of Mechanical Enginœers, Nagoya, 363 (in Japanese).

14) Hamrock, B. J., Fundamentals of Fluid Film Lubrication, McGraw-Hill, Inc. (1994) 472.

15) Zhu, D., "Elastohydrodynamic lubrication in extended parameter ranges - Part I: Speed effect ", Tribology Transactions, 45, 4 (2002) 540.

16) Patir, N. and Cheng, H. S., "An average flow model for determining effect of three-dimensional roughness on partial hydrodynamic lubrication " , ASME Journal of Tribology, 100 (1978) 12. 